Pesq. Vet. Bras. 35(3):216-222, março 2015

DOI: $10.1590 / \mathrm{S} 0100-736 \mathrm{X} 2015000300002$

\title{
Increased expression of Interleukin-6 related to nephritis in chickens challenged with an Avian infectious bronchitis virus variant ${ }^{1}$
}

\author{
Filipe S. Fernando ${ }^{2 *}$, Cintia H. Okino ${ }^{2,3}$, Ketherson R. Silva ${ }^{2}$, Camila C. Fernandes², \\ Mariana C.M. Gonçalves ${ }^{2}$, Maria F. S. Montassier², Rosemeri O. Vasconcelos ${ }^{2}$ \\ and Helio J. Montassier ${ }^{2}$
}

\begin{abstract}
Fernando F.S., Okino C.H., Silva K.R., Fernandes C.C., Gonçalves M.C.M., Oliveira E.S., Vasconcelos R.O. \& Montassier H.J. 2015. Increased expression of Interleukin-6 related to nephritis in chickens challenged with an Avian infectious bronchitis virus variant. Pesquisa Veterinária Brasileira 35(3):216-222. Laboratório de Imunologia e Virologia Veterinária, Departamento de Patologia Veterinária, Faculdade de Ciências Agrárias e Veterinárias, Universidade Estadual Paulista, Via de acesso Prof. Paulo Donato Castellane s/n, Jaboticabal, SP 14884-900, Brazil. E-mail: filipe.fernando@yahoo.com.br

A Brazilian field isolate (IBV/Brazil/PR05) of avian infectious bronchitis virus (IBV), associated with development of nephritis in chickens, was previously genotyped as IBV variant after S1 gene sequencing. The aim of this study was to evaluate the levels of IL-6 in kidneys and trachea of birds vaccinated and challenged with IBV/Brazil/PR05 strain, correlating these results with scores of microscopic lesions, specific IBV antigen detection and viral load. The up-regulation of IL- 6 and the increased levels of viral load on renal and tracheal samples were significantly correlated with scores of microscopic lesions. Reduced levels of viral load were detected in kidneys of birds previously vaccinated and challenged, compared to non-vaccinated challenged group, although markedly microscopic lesions were observed for both groups. The expression of IL-6, present both in the kidney and in the tracheas, was dependent on the load of the virus present in the tissue, and the development of lesions was related with IL-6 present in the tissues. These data suggest that variant IBV/Brazil/PR05 can induce the expression of proinflammatory cytokines in a manner correlated with viral load and increased IL-6 is involved in the tissue with the influx of inflammatory cells and subsequent nephritis. This may contribute with a model to the development of immunosuppressive agents of IL- 6 to prevent acute inflammatory processes against infection with IBV and perhaps other coronaviruses, as well as contribute to the understanding of the immunopathogenesis of IBV nephropatogenic strains.
\end{abstract}

INDEX TERMS: Interleukin-6, nephritis, infectious bronchitis virus, IBV, variant strain, chicken.

\section{RESUMO.- [Aumento da expressão de Interleucina-6 re- lacionada com nefrite in galinhas desafiadas com uma}

\footnotetext{
${ }^{1}$ Received on July 14, 2014.

Accepted for publication on December 10, 2014.

${ }^{2}$ Laboratório de Imunologia e Virologia Veterinária, Departamento de Patologia Veterinária, Faculdade de Ciências Agrárias e Veterinárias (FCAV), Universidade Estadual Paulista (Unesp), Via de acesso Prof. Paulo Donato Castellane s/n, Jaboticabal, SP 14884-900, Brazil. *Corresponding author: filipe.fernando@yahoo.com.br

${ }^{3}$ Embrapa Suínos e Aves, Rodovia BR-153 Km 110, Distrito de Tamanduá, Concórdia, SC 89700-000, Brazil.
}

variante do vírus da bronquite infecciosa.] Uma estirpe variante do vírus da bronquite infecciosa (VBI) associada com o desenvolvimento de nefrite em galinhas, foi isolado e identificado como variante por análise do gene S1. A estirpe IBV/Brazil/PR05 foi testada quanto à sua capacidade de induzir a expressão de interleucina-6 (IL-6) nos tecidos renais e traqueais. Galinhas vacinadas com a estirpe Massachusetts $\mathrm{H} 120$ e não vacinadas foram desafiadas com a estirpe IBV/Brazil/PR05. Cinco dias após a infecção, traquéias e rins foram coletados para análise por RT-qPCR, imunohistoquímica e histopatologia. Foi determinada a 
expressão relativa de IL-6 e da carga viral. A expressão de IL-6 e carga viral foram correlacionadas com o desenvolvimento de nefrite e lesão traqueal. A expressão de IL-6 foi maior quando houve aumento da carga viral na traqueia e nos rins. A carga viral presente nos rins foi inferior quando as aves foram vacinadas, entretanto foi observada nefrite acentuada. Houve alta correlação entre o desenvolvimento de nefrite e o nível de expressão de IL-6, bem como a expressão de IL-6 e a carga viral. A expressão de IL-6, presente tanto nos rins e nas traqueias, foi relacionada a carga viral presente nestes tecidos, e o desenvolvimento das lesões foi relacionado com a expressão de IL-6. Estes dados sugerem que a variante IBV/Brazil/PR05 pode induzir a expressão de citocinas pró-inflamatórias de forma correlacionada com a carga viral, e o aumento de IL-6 está envolvido com o influxo de células inflamatórias no tecido, o que evolui para o desenvolvimento de nefrite. Isto pode contribuir como um modelo para o desenvolvimento de agentes imunossupressores da IL- 6 para evitar processos inflamatórios agudos contra infecção com o VBI e talvez outros coronavírus, bem como contribuir para o entendimento da imunopatogênese das estirpes nefropatogênicas deste vírus.

TERMOS DE INDEXAÇÃO: Interleucina-6, nefrite, vírus da bronquite infecciosa, IBV, variante, galinhas.

\section{INTRODUCTION}

Coronaviruses (CoVs), members of the Coronaviridae family, are enveloped viruses with a positive-sense RNA genome. The avian infectious bronchitis virus (IBV), is the etiologic agent of infectious bronchitis (IB), an acute highly contagious disease and has been a major pathogen affecting the global poultry industry. IBV infects chickens and causes lesions in respiratory and urogenital organs (Cavanagh 2007). IBV replicates primarily on the upper respiratory tract and may be disseminated to other epithelial cells of other organs of the host (Dhinakar \& Jones 1996).

Some IBV strains replicate in the kidney, and due to their nephropathogenic properties they have the potential to cause severe losses (Cavanagh 2005). The presence of IBV in renal epithelial cells generates an acute interstitial inflammatory response with development of necrosis and nephritis (Abdel-Moneim et al. 2006).

In acute inflammatory response, several cytokines, including IL-6, are usually involved on increasing of exacerbation of immune response. IL- 6 is a major inducer of acute phase response. Studies have been shown increased expression of cytokines in birds after viral infection with Marek disease, Gumboro disease and with IBV (Sarson et al. 2006, Xing \& Schat 2000, Eldaghayes et al. 2006, Asif et al. 2007, Jang et al. 2013, Okino et al. 2014).

It has been reported that the spike glycoprotein $(S)$ of CoVs is a determinant of cell tropism (Kuo et al. 2000). A recombinant S protein of the SARS-CoVs was used to stimulate murine macrophages to evaluate the production of proinflammatory cytokines, showing that the expression of IL- 6 and TNF- $\alpha$ was directly related to the dosis and time after exposition with recombinant $\mathrm{S}$ protein (Wang et al.
2007), similarly to other coronaviruses, bringing an intriguing question about the pathogenesis caused by stimulation of IL- 6 after infection of epithelial cells in different tissues. In another model, after infecting human cells with influenza virus H5N1, it was shown that the H5N1 virus had greater potential to induce IL- 6 as compared to human H1N1 (Chan et al. 2005).

The aim of this study was to evaluate the expression levels of IL- 6 after IBV infection in tracheal and renal tissue samples from previously vaccinated and non-vaccinated birds, and correlate the obtained results with the development of renal and tracheal lesions with viral load.

\section{MATERIALS AND METHODS}

\section{Virus}

The isolate IBV/Brazil/PR05 (accession number GQ169242), grouped in the Brazilian BR-I genotype (data not shown), such as proposed by Chacon et al. (2011) and Fraga et al. (2013), was used in this study The IBV/Brazil/PR05 was propagated and titrated in 10-day-old specific pathogen-free (SPF) embryonated chicken eggs, via the allantoic sac route, and the fifty per cent embryo-infective doses $\left(\mathrm{EID}_{50}\right)$ were determined (Reed and Muench 1938). The commercial Massachusetts (Mass) H120 attenuated live strain was used for the immunisation.

\section{Experimental design}

Eighteen one day old White Leghorn SPF chickens were equally divided and housed into three isolators with positive pressure (I, II and III). At three weeks of age, group II received a full dose of attenuated $\mathrm{H} 120$ vaccine strain $\left(10^{4.0} \mathrm{EID}_{50} /\right.$ bird, as recommended by the manufacturer), while groups I and III received only the phosphate buffered saline (PBS). After three weeks, groups I and II received $10^{4.0} \mathrm{EID}_{50} /$ bird of IBV/Brazil/PR05 by intranasal and ocular routes, while group III (negative control group) was mock infected with SPF allantoic fluid. All birds were euthanized at 5 days post infection (dpi). Tracheal and renal samples were collected from each bird; a portion was immediately frozen and kept at $-70^{\circ} \mathrm{C}$ until processing, and the remaining portion was subjected to histopathological analysis.

\section{Histopathology}

Samples of kidney $(0.5 \mathrm{~g})$ and proximal, medial and distal trachea $(0.5 \mathrm{~cm}$ of each third) were placed in $10 \%(\mathrm{v} / \mathrm{v})$ buffered formalin ( $\mathrm{pH}$ 7.2) during one or two days. Next, the fixed fragments were dehydrated, diaphanized, embedded in paraffin, sectioned at $5 \mu \mathrm{m}$ and stained with hematoxylin and eosin (HE) or untreated to be used on immunohistochemistry analysis.

The slides were examined by light microscopy and the scores of lesions ranged from 0 to 3 according to the severity of the observed lesions. Absence of injury was classified as 0 , while mild, moderate and severe were classified as 1, 2, and 3 respectively (Nakamura et al. 1991; Chen et al. 1996).

\section{Immunohistochemistry}

The slides with fixed tissue samples were submitted to deparaffinization and rehydratation. Antigen retrieval was performed by heat, using a Pascal pressure chamber (Dako, USA). Endogenous phosphatase and nonspecific binding proteins were blocked using Dual Endogenous Enzyme Block (Dako, USA) and Protein Block (Dako, USA), respectively. The IBV-antigen was stained after incubation with goat hyperimmune polyclonal antisera against the recombinant nucleoprotein of IBV. The secondary conjugate EnVision $^{\mathrm{TM}}+$ Dual Link System HRP (Dako, Carpinteria, CA) was 
added and incubated for $30 \mathrm{~min}$ at room temperature, followed by chromogen substrate EnVision $^{\mathrm{TM}} \mathrm{G} \mid 2$ System/AP, Rb/Mo (Dako, Carpinteria, CA) added to slide for $30 \mathrm{~min}$ at room temperature. Counterstaining was carried out using Harris hematoxylin. The immunohistochemistry was carried out as described by Fernando et al.(2013).

\section{RNA extraction and Real time RT-qPCR}

The RNA extractions from tracheal and renal samples of experimentally infected chickens were performed using the Trizol Reagen $t^{\circledR}$ (Invitrogen, USA). The residual genomic DNA was digested by DNase treatment of RNA samples using a RNase-free DNase I kit (ThermoScientific, USA). The RNA quality was analyzed on a $1 \%$ gel and quantified by ultraviolet (UV) absorbance at $260 \mathrm{~nm}$ (A260). The cDNAs was synthesised according to instructions provided with SuperScript ${ }^{\circledR}$ enzyme (Invitrogen, USA) and using OligodT primers (IDT).

Real-time polymerase chain reaction (qPCR) was carried out using mixture contained 50ng of cDNA; $12.5 \mu \mathrm{L}$ of Maxima SYBR Green 2X (ThermoScientific, USA); 0.2 $\mu$ L Platinum Taq DNA polymerase (Life Technology, USA); $10 \mathrm{pmol}$ of each primer, and nuclease free water to a final volume of $20 \mu \mathrm{L}$. The amplification reaction included a preincubation step at $95^{\circ} \mathrm{C}$ for $10 \mathrm{~min}$, followed by 40 cycles of amplification including denaturation at $95^{\circ} \mathrm{C}$ for $30 \mathrm{sec}$, annealing at $45.5^{\circ} \mathrm{C}$ (S1 gene, described in Wang and Tsai, 1996) or $60^{\circ} \mathrm{C}$ (GAPDH and IL-6, described in Hong et al. 2006) for $30 \mathrm{sec}$ and extension at $72^{\circ} \mathrm{C}$ for $30 \mathrm{sec}$. Following amplification, a melting curve analysis was performed by raising the incubation temperature from $65^{\circ} \mathrm{C}$ to $95^{\circ} \mathrm{C}$ in $0.2^{\circ} \mathrm{C}$ increments with a hold of $1 \mathrm{sec}$ at each increment.

Absolute quantification of viral load was performed using oligonucleotides for S1 gene of IBV and the Ct results were used to calculate the log of the number of moles using the linear equation from standard curve, optimized previously (Okino et al. 2013).

\section{Statistical analysis}

Results were expressed as Mean \pm SEM. Data were analyzed statistically using GraphPad Prism software version 5.0 for windows (GraphPad Prism Software Inc., San Diego, CA, USA). Non parametric test (Mann Whitney test) was used to determine the statistical significance (if $p<0.05$ ). The results from viral load and relative expression of IL- 6 between the trachea and kidney tissues were analyzed to see if there was any significant difference between the tested groups and control group. Correlations were determined by Spearman rank correlation coefficients.

\footnotetext{
RESULTS

Clinical signs and gross pathology

From 2 to $5 \mathrm{dpi}$, all birds from group I presented respiratory signs (sneezing, tracheal rales and hoarseness), wherein $4 / 6$ birds were depressed and one bird died. No clinical signs were observed in the groups II and III.

Macroscopic alterations were observed in renal and respiratory tract of challenged groups (I and II), kidneys were found edematous with some pale spots, and tracheas presented mucoid exudate in the lumen. Most striking tracheal lesions were observed on group I, where a hyperemia with catarrhal exudate was noted in some animals.

None of birds from group III presented macroscopic lesions and no changes were observed in lung, spleen, air sacs, caecal tonsil, intestine and reproductive tissues from all experimental groups.
}

\section{Histopathology}

The tracheal microscopic changes were more prominent in animals from group I, presenting moderate epithelial deciliation, epithelial hyperplasia, degeneration of the mucus-producing cells and infiltration of heterophils and lymphocytes in the lamina propria and submucosa. Furthermore, a mild infiltration of heterophils in the lamina propria and mild desquamation of ciliated cells in tracheal samples from birds of group II were observed.

All birds from groups I and II had intense multifocal nephritis, presenting lymphoplasmacytic infiltrate, (especially in distal collecting tubules) (Fig.1). In some birds of both challenged groups (I and II), mild necrosis of renal



Fig.1. Histopathologic analysis of kidney from chicken vaccinated with the Massachusetts strain and challenged with infectious bronchitis virus IBV/Brazil/PR05 strain. Intense nephritis showing the characteristic lymphoplasmacellular interstitial nephritis (\#) and mild necrosis of renal epithelial cells (white arrow). Hematoxilin and Eosin. Scale bar $=50 \mu \mathrm{m}$.

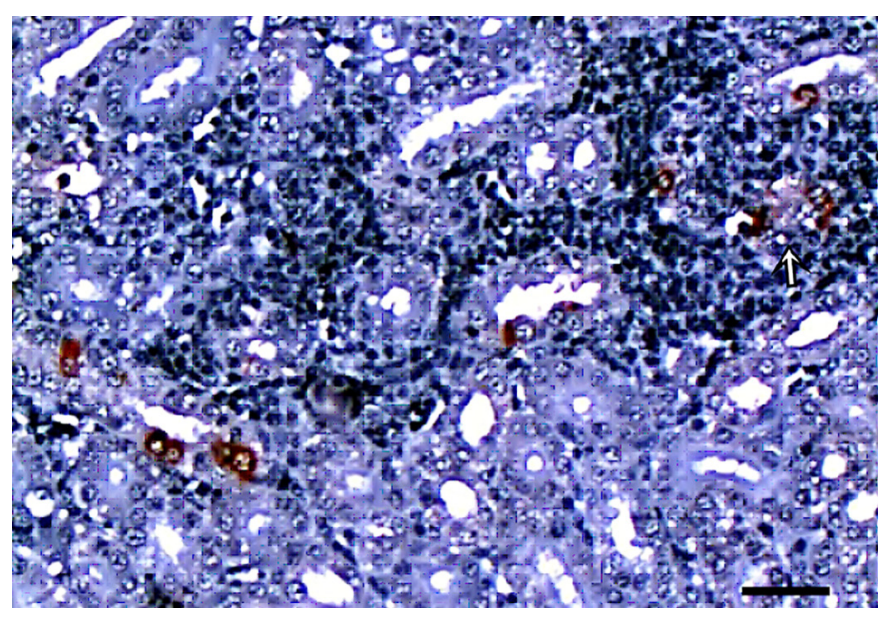

Fig.2. Immunohistochemistry analysis of kidney from chicken vaccinated with the Massachusetts strain and challenged with infectious bronchitis virus IBV/Brazil/PR05 strain. It is possible to observe the specificity of immunostaining for IBV in the cytoplasm of the tubular epithelium associated to inflammatory cells around (white arrow). Polymer-based Immunohistochemistry

Methods. Scale bar $=50 \mu \mathrm{m}$ 
epithelial cells, urates in tubules and proteinaceous material were observed.

No microscopic alterations in tracheal samples were observed in the negative control group (III), although moderate necrosis and epithelial degeneration were found in kidneys.

\section{Immunohistochemistry}

The presence of IBV antigen was detected in all tissue samples from tracheas and kidneys from both challenged groups. There was labeling in the cytoplasm of epithelial cells of the mucosa and lamina propria of the trachea. More intense staining of viral antigen in tracheal samples was noticed within the group I. IBV antigen in the kidney is shown in Figure 2, as a staining of renal tubular epithelium, well as inflammatory cells have migrated to sites of IBV infected cells, around the tubular epithelial cells.

No specific IBV antigen staining was found in tracheal and renal samples from negative control group (III).

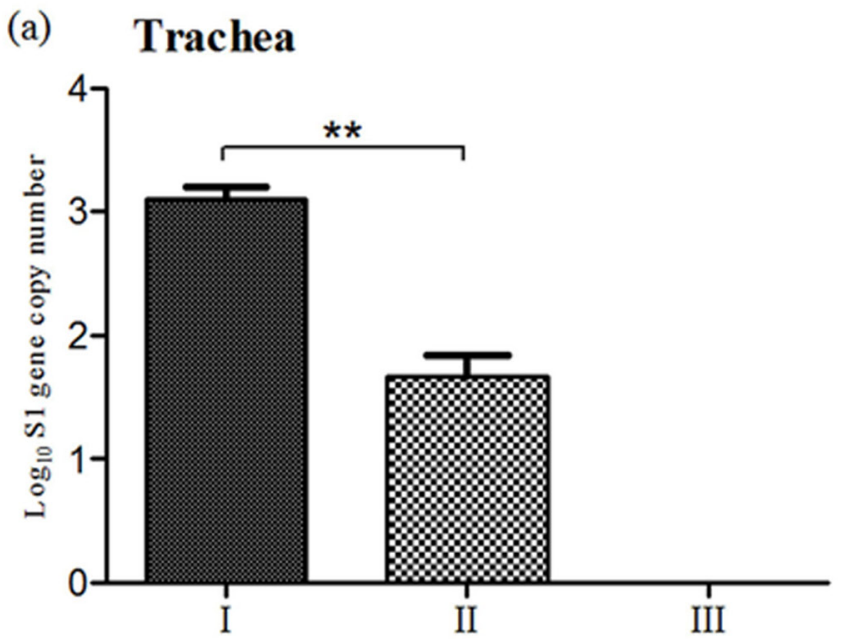

(b) Kidney



Fig.3. Viral RNA load measured by real time RT-qPCR in tracheas and kidneys of vaccinated and non-vaccinated groups. 3(a) Representation of absolute quantification of the number of viral copies $\left(\log _{10}\right)$ tracheas present in the non-vaccinated and challenged (I), vaccinated and challenged (II) and mock group (III). 3(b). Absolute quantification of viral load in the kidneys present in groups I, II and III. ${ }^{*} p<0.05,{ }^{* *} p<0.01$. (a)

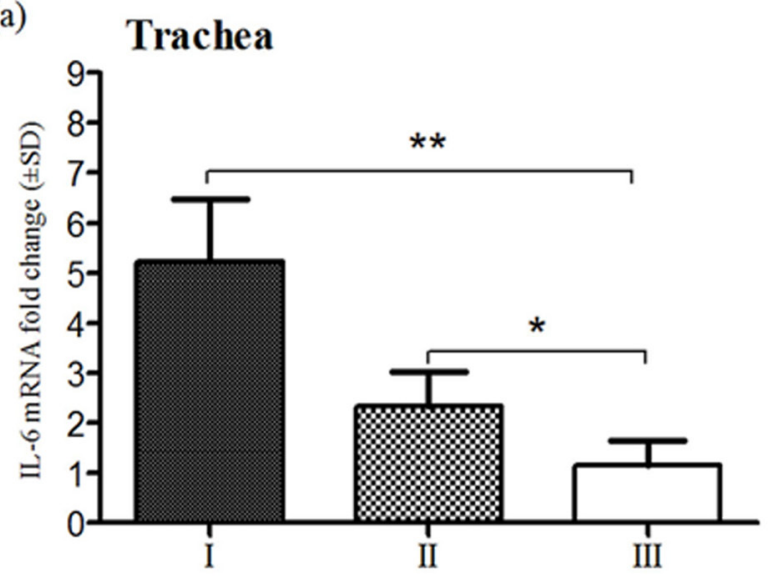

(b) Kidney

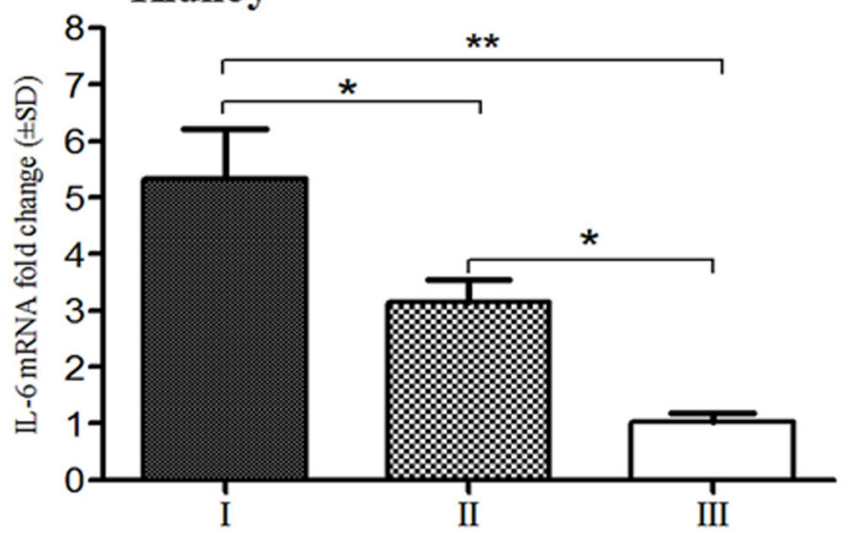

Fig.4. Mean fold changes in the mRNA expression of IL-6 by experimentally infection with IBV/Brazil/PR05 isolate in non-vaccinated and challenged chickens (I), vaccinated and challenged chickens (II) and mock group (III). 4(a) Relative expression of IL-6 was evaluated by RT-qPCR from tracheas. 4(b) Relative expression of IL- 6 was evaluated by RT-qPCR from kidneys. Significant differences between the groups were detected using the Mann Whitney test. Standard error bars are displayed. ${ }^{*} p<0.05,{ }^{* *} p<0.01$.

\section{Viral load related to up-regulation of IL-6}

Figure 3a shows greater presence of viral RNA in the trachea of the group I which increased from group II to I $(p<0.01)$. This result was similar in kidney samples which contained greater number of viral copies in group I $(p<0.05)$. Taking into account the numbers of copies of viral RNA present in the trachea and kidneys from group I, one notable difference was observed between them, in which the viral load in the kidneys was higher than in the trachea $(p<0.05)$. This result was repeated in the group II (Fig.3b), demonstrating that this variant strain has a higher renal tropism.

Induction of the relative expression of IL- 6 had a positive correlation with the number of viral copies present in the kidneys (Spearman $r=0.6669)$ and trachea $(r=0.5560)$ of non-vaccinated group. The group II showed correlation data in renal tissue $(r=0.7900)$, but there was no correlation in the trachea. Group I showed increased expression of IL- 6 both in kidney tissue and in tracheal, however, only the expression of IL-6 significantly increased in the kid- 
neys compared to the vaccinated group $(\mathrm{p}<0.05)$ and the control group $(p<0.01)$. The results concerning the expression of IL-6 in the trachea had no significant increase in the non-vaccinated group than vaccinated group ( $p>0.05)$, but these groups showed higher expression than control group $(\mathrm{p}<0.05)$ (Fig.4a).

\section{Association of IL-6 and induction of nephritis}

There was no correlation between the expressions of IL- 6 in the trachea with tracheal injury scores in the vaccinated group. However, the tracheal lesion development associated with IL-6 in group I was evident ( $\mathrm{r}=0.8721)$. A high correlation between the expression of IL- 6 in the development of nephritis in group I ( $\mathrm{r}=0.9174)$ and II $(\mathrm{r}=0.7906)$ was also found.

\section{DISCUSSION}

IL-6 plays an important role in the acute phase of infection, including induction and proliferation of macrophages $(\mathrm{Hi}-$ rano 1998). Previous studies regarding SARS-CoV showed that it induced the production of IL- 6 and TNF- $\alpha$ in human macrophages (Law et al. 2005). Studies also showed that the genetic structure of the chicken IL-6 is similar to mammalian IL-6 (Kaiser et al. 2001, Schneider et al. 2001), and therefore, it is interesting to know whether Avian coronavirus can act similarly in cells of chickens and induce the production of IL-6 in the same way as human coronaviruses.

The nephropathogenic T strain of IBV induces increased expression of IL-6 at different levels and cause nephritis depending on the lineage of chicken infected (Asif et al. 2007). However, there's no information related to the viral load-dependent increased expression of pro-inflammatory cytokines and pathogenic damage caused to these organs in vivo. Our results suggest that increased expression of IL-6 was induced by viral load in the trachea of non-vaccinated and kidneys from vaccinated and non-vaccinated chickens after challenge and the consequent development of inflammation in the kidneys, characterized by nephritis. The fact that there is no correlation between the parameters of the trachea in the vaccinated group may be related to a low viral load due to cross-protection of the vaccine developed in the trachea, and thus a lower capacity of IL-6 induction.

Kuo et al. (2000) demonstrated that the spike protein $\mathrm{S}$ is largely responsible for the tissue tropism. S1 glycoprotein is responsible for viral infectivity and contains the antigenic determinants that induce the formation of neutralizing antibodies. The variation in the composition of amino acids in some regions of the $\mathrm{S}$ glycoprotein constitutes thus the main strategy of IBV to escape the host defense mechanisms and migration to other tissues (Cavanagh et al. 1997, Keeler et al. 1998). It is therefore likely that the genetic changes in the composition of the $S$ glycoprotein may be associated not only with tropism but also with the ability to induce a potential increase in the secretion of pro-inflammatory factors such as IL-6, and thereby trigger inflammation.

Previous reports have shown that heterogeneous strains of respiratory syncytial virus (RSV) differ in their ability to induce IL- 6 and CCL5 after RSV infection. The in- duction of IL- 6 was related to the viral dosis in cells, and simultaneously one of the strains induced IL-6 in the same proportion when a dosis 10 times higher was used (Levitz1 et al. 2012). Likewise, cell lines treated with $S$ protein of the SARS-CoVs stimulate the expression of pro-inflammatory cytokines such as IL- 6 and TNF- $\alpha$ in a dosis and time-dependent exposure regarding the virus (Wang et al. 2007). Our data suggest that the induction of IL-6 correlates with viral load in epithelial cells which are exposed to IBV.

Regarding IBV, high titers of virus in the trachea and kidney tissues are not always related to the disease or tissue changes, such as strain Moroccan G, which, despite the viral load in trachea and kidneys, lead to no gross lesions in these organs (Ambali and Jones, 1990, revised by Cavanagh, 2007). This may be similar to what has been proposed for RSV, suggesting that the induction of pro-inflammatory cytokines relates to genetic polymorphisms of the virus (Levitz1 et al. 2012). The IBV/Brazil/PR05 strain is a S1 variant IBV, and regarding the results presented herein, it's nephropathogenic and the induction of IL- 6 may be related to genetic variation of the S1 gene and its consequent induction of proinflammatory cytokines, agreeing with other studies using models of RNA virus (Hornsleth et al. 1998, Montassier et al. 2008, Levitz et al. 2012, Montassier et al. 2012).

In our study, we found an accumulation of inflammatory cells around the tubular epithelial cells stained for antigen detection by immunohistochemistry. This may be related to induction of chemokines molecules and adhesion due to increased amount of IL- 6 expressed by epithelial cells containing IBV, facilitating the migration of leukocytes (Hirano 1998). The IL- 6 could then have caused an increased expression of IL6 and IL18 after nephropatogenic IBV strain infection after 5 dpi (Cong et al. 2013). Our data suggest that both increased expression of IL-6 and viral load contribute to the damage induced to kidney tissues by nephropatogenic IBV infection. Similar data were reported after experimental infection with one genotype of the IBV, which induced higher expression of IL-6, associated with higher viral load in kidneys (Jang et al. 2013).

The relative expression of IL- 6 had a positive correlation with the number of viral copies present in the trachea of the non-vaccinated group. Previous reports have shown that Massachusetts strain (M41), induces highest values of histopathology scores in the trachea and viral load associated with peaks of the expression of inflammatory cytokines, including the IL-6, in non-vaccinated and challenged chickens (Okino et al. 2014). However, there was no correlation between the parameters of the trachea in the vaccinated group. This might be related to a low viral load due to cross-protection of the vaccine developed in the trachea, and so less capacity exacerbated induction of IL-6.

Many variants of IBV strains have been isolated and characterized as nephropathogenic worldwide. Also, vaccine protection tests were done with these strains, and they showed good results of vaccine protection against homologous strains (Xiel et al. 2011), and also with heterologous strains (Lee et al. 2010). Our data indicate that there was a better vaccine protection in the trachea due to lower lesion score and viral RNA expression. We have a hypothesis that 
induction of protection by vaccination in the trachea prevented the exacerbation of expression of IL- 6 and thus there was less inflammatory infiltrate and lesion. In the kidney tissue, although there is a significant reduction in the viral RNA expression, lesions and severity of nephritis surprisingly still continued even in the vaccinated chickens.

In summary, our data suggest that the viral load can induce the up-regulation of IL-6, and peaks of expression of IL-6 can induce the development of nephritis in both vaccinated and non-vaccinated chickens. IBV S1 variants strains show several ways of pathogenesis and virulence. Identification of the genetic polymorphisms associated with variations in the pathogenesis and up-regulation of pro-inflammatory cytokines is important to understand the regulatory mechanisms in chickens and disease. This may lead to insights into IBV-associated diseases.

Ethics Committee and Biosafety.- This study was approved by the Institutional Ethics and Animal Welfare Committee (Comissão de Ética no Uso de Animais - CEUA, Unesp, protocol number 011467/11).

Acknowledgements.- We would like to thank Fundação de Amparo à Pesquisa do Estado de São Paulo (FAPESP, grant no. 2011/04743-2) and CNPq for their financial support. The authors wish to acknowledge Mrs. F.A. Ardisson for her histotechnical assistance and Professor A.C. Alessi for histopathologic analysis.

\section{REFERENCES}

Abdel-Moneim A.S., El-Kady M.F., Ladman B.S. \& Gelb Jr J. 2006. S1 gene sequence analysis of a nephropathogenic strain of avian infectious bronchitis virus in Egypt. Virology J. 3(78):1-9.

Ambali A.G. \& Jones R.C. 1990. Early pathogenesis in chicks of infection with an enterotropic strain of infectious bronchitis virus. Avian Dis. 34(4):809-817.

Asif M., Lowenthal J.W., Ford M.E., Schat K.A., Kimpton W.G. \& Bean A.G.D. 2007. Interleukin-6 Expression after Infectious Bronchitis Virus Infection in Chickens. Viral Immunol. 20(3):479-486.

Cavanagh D., Ellis M.M. \& Cook J.K.A. 1997. Relationship between sequence variation in the S1 spike protein of infectious bronchitis virus and the extent of cross-protection in vivo. Avian Pathol. 26(1):63-74.

Cavanagh D. 2005. Coronaviruses in poultry and other birds. Avian Pathol. 34(6):439-448.

Cavanagh D. 2007. Coronavirus avian infectious bronchitis virus. Vet. Res. 38(2):281-297.

Chacón J.L., Rodrigues J.N., Assayag Júnior M.S., Peloso C., Pedroso A.C. \& Ferreira A.J.P. 2011. Epidemiological survey and molecular characterization of avian infectious bronchitis virus in Brazil between 2003 and 2009. Avian Pathol. 40(2):153-162.

Chan M.C.W., Cheung C.Y., Chui W.U., Tsao S.W., Nicholls J.M., Chan Y.O., Chan R.W.Y., Long H.T., Poon L.L.M., Guan Y. \& Peiris J.S.M. 2005. Proinflammatory cytokine responses induced by influenza A (H5N1) viruses in primary human alveolar and bronchial epithelial cells. Respiratory Res. 6(135):1-13.

Chen B.Y., Hosi S., Nunoya T. \& Itakura C. Histopathology and immunohistochemistry of renal lesions due to infectious bronchitis virus in chicks. Avian Pathol. 25(2)-269-283.

Cong F., Liu X., Han Z., Shao Y., Kong X. \& Liu S. 2013. Transcriptome analysis of chicken kidney tissues following coronavirus avian infectious bronchitis virus infection. BMC Genomics 14:743.

Dhinakar R.G. \& Jones R.C. 1996. Immunopathogenesis of infection in SPF chickens and commercial broiler chickens of variant infectious bronchitis virus of economic importance. Avian Pathol. 25:481-501.

Eldaghayes I., Rothwell L., Williams A., Withers D., Balu S., Davison F. \& Kaiser P. 2006. Infectious bursal disease virus: strains that differ in vir- ulence differentially modulate the innate immune response to infection in the chicken bursa. Viral Immunol. 19(1):83-91.

Fernando S.F., Montassier M.F.S., Silva K.R., Okino C.H., Oliveira E.S., Fernandes C.C., Bandarra M.B., Gonçalves M.C.M., Borzi M.M., Santos R.M., Vasconcelos R.O., Alessi A.C. \& Montassier H.J. 2013. Nephritis associated with a S1 variant brazilian isolate of infectious bronchitis virus and vaccine protection test in experimentally infected chickens. Int. J. Poult. Sci. 12(11):639-646.

Fraga A.P., Balestrin E., Ikuta N., Fonseca A.S.K., Spilki F.R., Canal C.W. \& Lunge V.R. 2013. Emergence of a new genotype of avian infectious bronchitis virus in Brazil. Avian Dis. 57:225-232. Hirano T. 1998. Interleukin 6, p.197-227. In: Thomson A.E. (Ed.), The Cytokine Handbook. $3^{\text {rd }}$ ed. Academic Press, San Diego.

Hong Y.H. 2006. Analysis of chicken cytokine and chemokine gene expression following Eimeria acervulina and Eimeria tenella infections. Vet. Immunol. Immunopatol. 114:209-223.

Hornsleth A., Klug B., Nir M., Johansen J., Hansen K.S., Christensen L.S. \& Larsen L.B. 1998. Severity of respiratory syncytial virus disease related to type and genotype of virus and to cytokine values in nasopharyngeal secretions. Pediatr. Infect. Dis J. 17:1114-1121.

Kaiser P., Bumstead N., Goodchild M., Atkinson D. \& Rothwell L. 2001. Characterising chicken cytokine genes, IL-1 $\beta$, IL-6, IL-15 and IL-18, p.27-32. In: Schat K.A. (Ed.), Current Progress on Avian Immunology Research. Proc. $7^{\text {th }}$ Avian Immunology Research Group, Ithaca, NY. American Association of Avian Pathologists, Inc., Pennsylvania.

Keeler C.L., Reed K.L., Nix W.A. \& Gelb Jr J. 1998. Serotype identification of avian infectious bronchitis virus by RT-PCR of the peplomer (S-1) gene. Avian Dis. 42:275-284.

Jang H., Koo B., Jeon E., Lee H., Lee S. \& Mo I. 2013. Altered pro-inflammatory cytokine mRNA levels in chickens infected with infectious bronchitis virus. Poult. Sci. 92(9):2290-2298.

Kuo L., Godeke G.J., Raamsman M.J., Masters P.S. \& Rottier P.J. 2000. Retargeting of coronavirus by substitution of the spike glycoprotein ectodomain: crossing the host cell species barrier. J. Virol. 74:1393-1406.

Law H.K., Cheung C.Y., Ng H.Y., Sia S.F., Chan Y.O., Luk W., Nicholls J.M., Peiris J.S. \& Lau Y.L. 2005. Chemokine up-regulation in SARS coronavirusinfected, monocyte-derived human dendritic cells. Blood. 106:23662374.

Lee H.J., Youn H.N., Kwon J.S., Lee Y.J., Kim J.H., Lee J.B., Park S.Y., Choi K.S. \& Song C.S. 2010. Characterization of a novel live attenuated infectious bronchitis virus vaccine candidate derived from a Korean nephropathogenic strain. Vaccine. 28:2887-2894.

Levitz R., Wattier R., Phillips P., Solomonl A., Lawler J., Lazar I., Weibel C. \& Kahn J.S. 2012. Induction of IL-6 and CCL5 (RANTES) in human respiratory epithelial (A549) cells by clinical isolates of respiratory syncytial virus is strain specific. Virol. J. 9(190):1-9. <http://www.virologyj.com/ content/9/1/190>

Livak K.J. \& Schmittgen T.D. 2001. Analysis of relative gene expression data using real time quantitative PCR and the $2^{-\Delta \Delta C T}$ method. Methods. 25:402-408.

Montassier M.F.S., Brentano L., Montassier H.J. \& Richtzenhain L.J. 2008. Genetic grouping of avain infectious bronchitis virus isolated in Brazil based on RT-PCR/RFLP analysis of the S1 gene. Pesq. Vet. Bras. 28:190194.

Montassier M.F.S., Brentano L., Richtzenhain L.J. \& Montassier H.J. 2012. Molecular analysis and evolution study of infectious bronchitis viruses isolated in Brazil over a twenty-one-year period. Proceedings of the 7th International Symposium on Avian Corona and Pneumoviruses and Complicating Pathogens. Vol.1. Druckerei Schoreder, Wetter, Germany, p.19-30.

Nakamura K., Cook J.K.A., Otsuki K., Huggins M.B. \& Frazier J.A. 1991. Comparative study of respiratory lesions in two chicken lines of different susceptibility infected with infectious bronchitis virus: histology, ultrastructure and immunohistochemistry. Avian Pathol. 20:241-257.

Okino C.H., Alessi A.C., Montassier M.F.S., Rosa A.J.M., Wang X. \& Montassier H.J. 2013. Humoral and Cell-Mediated Immune Responses to Dif- 
ferent Doses of Attenuated Vaccine Against Avian Infectious Bronchitis Virus. Viral Immunol. 26(4):259-267.

Okino C.H., Santos I.L., Fernando F.S., Alessi A.C., Wang X. \& Montassier H.J. 2014. Inflammatory and cell-mediated immune responses in the respiratory tract of chickens to infection with Avian Infectious Bronchitis virus. Viral Immunol. $27(8): 383-391$.

Sarson A.J., Abdul-Careem M.F., Zhou H. \& Sharif S. 2006. Transcriptional analysis of host responses to Marek's disease viral infection. Viral Immunol. 19:747-758.

Schneider K., Klaa R., Kaspers B. \& Staeheli P. 2001. Chicken interleukin-6 cDNA structure and biological properties. Eur. J. Biochem. 268:42004206.
Xiel Q., Ji J., Xiel J., Chen F., Cai M., SunB., Xue C., Ma J. \& Bi Y. 2011. Epidemiology and immunoprotection of nephropathogenic avian infectious bronchitis virus in southern China. Virol. J. 8(484):1-5.

Xing Z. \& Schat K.A. 2000. Expression of cytokine genes in Marek's disease virus-infected chickens and chicken embryo fibroblast cultures. Immunol. 100:70-76.

Wang C.H. \& Tsai C.T. 1996. Genetic grouping for the isolates of avian infectious bronchitis virus in Taiwan. Arch. Virol. 141(9):1677-1688.

Wang W., Ye L., Ye L., Li B., GaoB., Zeng Y., Kong L., Fang X., Zheng H., Wu Z. \& She Y. 2007. Up-regulation of IL-6 and TNF- $\alpha$ induced by SARS-coronavirus spike protein in murine macrophages via NF- $\mathrm{\kappa B}$ pathway. Virus Res. 128(1/2):1-8. 